\title{
FORUM DISKUSI ONLINE (OnTeLL) SEBAGAI WAHANA PEMBELAJARAN BAHASA INGGRIS: SEBUAH ANALISIS KONTEN
}

\author{
Oleh : Urai Salam, M.CALL, Ph.D ${ }^{1}$
}

\begin{abstract}
Abstrak : Hal terpenting dari proses pembelajaran bahasa asing adalah kesempatan untuk menggunakan bahasa target dalam kontek sesungguhnya. Oleh karena itulah, penulis membuat sebuah ruang virtual yang dinamakan OnTeLL (Online Teaching and Language Learning) sebagai tempat 'praktek' penggunaan bahasa target, bahasa Inggris. Di sana para mahasiswa berdiskusi tentang topictopik yang mereka pelajari pada mata kuliah Teaching Learning with ICT dengan menggunakan bahasa Inggris.Penelitian ini bertujuan untuk mengetahui apakah proses pembelajaran benarbenar terjadi ketika mahasiswa mengikuti diskusi online tersebut. Data yang diambil dari transkrip diskusi online dianalisis dengan metode content analysis dengan framework yang dibuat oleh Gunawardena, Lowe, dan Anderson (1997). Hasilnya, kualitas diskusi mereka bervariasi dari level 1, 2, dan 3 .
\end{abstract}

Kata kunci: diskusi online, proses belajar, analisis konten, CT.

\section{PENDAHULUAN}

Maraknya penggunaan komputer yang berkembang dengan pesat telah mempengaruhi banyak aspek dalam kehidupan manusia, termasuk pembelajaran bahasa Inggris. Teknologi tersebut digunakan untuk menunjang proses pembelajaran, demi memuwujudkan visi dan misi pendidikan yaitu melahirkan generasi penerus bangsa yang cakap dan kreatif. Selain itu, kehadiran computer dalam proses pembelajaran secara keseluruhan melahirkan sebuah dinamika baru, dimana proses belajar mengajar tidak lagi harus terbatas ruang dan waktu sehingga tidak ada batasan baik bagi pendidik maupun peserta didik untuk memperoleh informasi yang menunjang ilmu pengetahuan mereka.

Isu paling mencolok dari penggunaan komputer dalam dunia pendidikan, khususnya dalam pembelajaran bahasa Inggris, adalah ketersediaan akses Internet yang sekarang mulai menjamur dimana-mana. Berbagai macam

${ }^{1}$ Urai Salam, M.CALL, Ph.D : Dosen Prodi Pend. Bahasa Inggris FKIP Untan 
fasilitas ditawarkan seperti media telusur, jejaring social, penyedia layanan surat elektronik, game online, dan masih banyak lagi. Sayangnya, hanya sedikit dari fasilitas-fasilitas tersebut yang digunakan untuk menunjang proses pembelajaran. Padahal, jika para pemangku kepentingan di dunia pendidikan mau berfikir kreatif, banyak sekali cara yang dapat digunakan untuk lebih memaksimalkan ketersediaan Internet dalam menunjang proses pembelajaran.

Salah satu fasilitas Internet yang dapat dijadikan media untuk menunjang pembelajaran bahasa Inggris adalah milis. Milis adalah sebuah alamat surat elektronik yang digunakan oleh sekelompok pengguna Internet untuk melakukan kegiatan tukar menukar informasi. Setiap pesan yang dikirim ke alamat sebuah milis, secara otomatis akan diteruskan ke alamat surat elektronik seluruh anggotanya. Milis umumnya dimanfaatkan sebagai sarana diskusi atau pertukaran informasi diantara para anggotanya. Dengan menggunakan milis, peserta didik dapat saling bertukar informasi dan berdiskusi mengenai topik yang diberikan, sehingga terjadi pertukaran ide yang dapat menambah wawasan mereka, serta mendorong mereka untuk dapat lebih berpikir kritis mengenai suatu masalah.

Milis atau mailing list dalam penelitian ini berfungsi sebagai kelas virtual yang dapat diakses oleh para mahasiswa kapanpun dan dimanapun. Yang menarik dari kelas virtual ini menurut beberapa ahli seperti Scheuermann et al.( 2003), Garrison, Anderson, and Archer (2001) dan 2003) adalah ia dapat meningkatkan partisipasi dan keinginan anggota kelas untuk ikut aktif dalam diskusi kelas. Karena didalam kelas tersebut mereka tidak berhadapan face to face, kepercayaan diri untuk menggunakan bahasa target menjadi lebih kekuasa; mereka tidak terbebani oleh rasa malu dan takut salah dengan bahasa Inggris yang mereka gunakan. Selain itu, mereka memiliki cukup waktu untuk mereview bahasa mereka sebelum mereka mengirim pesan tersebut ke forum diskusi.

Dengan demikian forum diskusi seperti ini memberikan keuntungan bagi mahasiswa dalam hal peningkatan kemampuan mereka berbahasa Inggris. Mereka tidak hanya belajar tentang bahasa Inggris, tapi juga belajar bagaimana cara menggunakan bahasa tersebut dalam konteks sesungguhnya. Forum seperti ini juga menjadi test case dan sebuah tantangan apakah bahasa Inggris mereka sudah cukup bagus untuk berkomunikasi. Selain itu, mahasiswa juga memiliki kesempatan untuk mengekspresikan pendapat mereka terhadap topik yang diberikan. Dengan demikian, media ini dapat membantu mahasiswa dalam membangun pemahaman mereka tentang banyak hal (Land, Choi, \& Ge, 2007; Haavind, 2006; Richardson \& Ice, 2010). Keuntungan lain yang ditawarkan oleh media ini dikemukakan oleh 
Hirumi and Bermudez (1996, dalam Rovai, 2007) yakni dapat memenuhi kebutuhan mahasiswa akan umpan balik yang lebih personal dimana hal tersebut tidak dapat ditemukan dalam pertemuan face to face.

Walaupun proses pembelajaran seperti ini dapat dikatakan sebagai inovasi dalam pembelajaran bahasa Inggris, namun tidak sedikit juga yang meragukan apakah benar pembelajaran dapat terjadi di dalam situasi seperti itu. Untuk mengetahuinya, kita harus menganalisis kualitas diskusi yang terjadi di forum diskusi tersebut. Jika diskusi yang berlangsung memiliki kualitas yang baik, maka dapat dikatakan bahwa kelas virtual yang dalam penelitian ini desebut OnTeLL dapat member manfaat sebagai media untuk meningkatkan kemampuan berbahasa Inggris. Para ahli terdahulu telah banyak melakukan penelitian serupa untuk mengetahui hal tersebut. Salah satunya dengan menggunakan analisa konten yang dicetuskan oleh Gunawardena et al (1997) yang menganalisa proses pertukaran informasi yang terjadi selama diskusi berlangsung. Analisa konten ini akan digunakan untuk menganalisa diskusi yang terjadi di forum diskusi online di kelas Teaching Learning with ICT.

\section{TEKNOLOGI INFORMASI DAN KOMUNIKASI (TIK) DALAM PEMBELAJARAN BAHASA INGGRIS}

Pendidikan adalah salah satu dari sekian banyak bidang kehidupan yang terkena dampak dari perkembangan teknologi, khususnya Internet. Teknologi ini membawa dunia pendidikan Indonesia ke era baru dalam proses pembelajaran bahasa Inggris, dimana Internet berperan dalam meningkatkan motivasi pelajar untuk lebih membuka wawasan; memperdalam pengetahuan mereka tentang dunia luar yang menunjang kemampuan mereka untuk berbahasa Inggris (Warschauer, 1996a, dikutip dalam Samuel, 2001).

Seiring dengan berkembangnya teknologi, beberapa model pembelajaran baru juga muncul dalam dunia pendidikan. Sekarang, istilahistilah seperti Electronic Learning (E-Learning), Web-Based Education, Virtual Environment, CMC (Computer-Mediated Environment) dan lain-lain sudah menjadi buzz words dalam dunia pendidikan. Semuanya itu merupakan sebuah situasi dimana pembelajaran terjadi melalui media Internet. Menurut Carliner (2004:1), model pembelajaran seperti ini hanya bisa terjadi dengan adanya komputer. Dengan segala bentuknya pendidikan berbasis web memungkinkan proses pembelajaran jarak jauh yang tak terasa jauh; proses asynschronous yang terasa synchronous; proses yang tidak hanya tidak terhalang oleh batas jarak dan waktu tetapi yang bisa melibatkan multi media dan multi sumber (multiple outsourcing). Keunggulan seperti 
itulah yang membuat para pakar pendidikan memandang perlu menggali potensi teknologi untuk proses pembelajaran (Hew \& Cheung, 2008) dan lebih khusus untuk proses pembelajaran bahasa asing. Penelitian ini juga bermaksud menggali potensi tersebut.

E-Learning sendiri memiliki banyak definisi. E-Learning merupakan suatu jenis belajar mengajar yang memungkinkan tersampaikannya bahan ajar ke siswa dengan menggunakan media Internet atau jaringan komputer lain. Definisi yang lebih sederhana lagi dikemukakan oleh Wahono (2003) yang menyatakan bahwa E-Learning merupakan sistem atau konsep pendidikan yang memanfaatkan teknologi informasi dalam proses belajar mengajar.

Menurut Suryadi (2007), pemanfaatan teknologi seperti ini memiliki beberapa dampak positif, yaitu mampu menciptakan kondisi belajar yang menyenangkan dan mengasyikan. Selain itu, pelajar juga dibekali dengan kemampuan untuk menggunakan teknologi tinggi. Lingkungan belajar konstruktivis juga turut dibangun dengan memberikan pelajar kesempatan untuk berlatih dengan tugas-tugas yang berbasis penyelesaian masalah (problem-based learning).

Salah satu bentuk pembelajaran bahasa Inggris berbasis E-Learning adalah dengan memanfaatkan milis. Setiap pesan yang dikirimkan ke alamat sebuah milis, secara otomatis akan diteruskan ke alamat email seluruh anggotanya. Milis umumnya dimanfaatkan sebagai sarana diskusi atau pertukaran informasi diantara para anggotanya. Penggunaan teknologi seperti ini dapat meningkatkan interaksi antara pendidik dan pelajar, sikap mereka terhadap belajar, evaluasi dari pengalaman belajar mereka, dan membuat proses belajar lebih terpusat pada pelajar itu sendiri (student centred process.

\section{BLENDED ENVIRONMENT DALAM PEMBELAJARAN BAHASA INGGRIS}

Model pembelajaran populer yang muncul akibat invasi ICT dalam dunia pendidikan adalah adanya kombinasi antara pertemuan tatap muka dan virtual class dengan menggunakan fasilitas Internet untuk menciptakan proses pembelajaran yang efektif tanpa adanya batasan ruang dan waktu yang disebut dengan blended learning. Stacey dan Gerbic (2009) berpendapat bahwa blended learning adalah kombinasi antara pertemuan tatap muka dan pembelajaran jarak jauh yang dimungkinkan dengan adanya perkembangan teknologi dan komunikasi dan disertai dengan tuntutan adanya flexibilitas dalam pembelajaran. Definisi serupa diungkapkan oleh Sharma dan Banrit (2007) yakni blended learning merupakan perpaduan antara pertemuan tatap 
muka dengan penggunaan teknologi dalam proses belajar mengajar. Mereka juga mengungkapkan beberapa keunggulan teknologi dalam pembelajaran, yaitu:

1. Motivasi: pelajar lebih menyatu dengan tugas yang diberikan dan pada saat yang sama, mereka meningkatkan kemampuan berbahasa Inggris.

2. Interaktif: semua pelajar bisa mengakses teknologi yang disediakan

3. Umpan balik: pelajar depat dengan segera menerima umpan balik dalam berbagai bentuk.

Pertemuan tatap muka mempermudah mahasiswa untuk mendapatkan arahan langsung dari dosen saat proses pembelajaran berlangsung di dalam kelas. Sedangkan virtual class dipilih untuk meningkatkan kreativitas mereka, memperluas wawasan, serta menambah pengalaman mereka belajar dalam situasi pembelajaran yang baru. Selain itu, virtual class juga memberikan kelonggaran waktu bagi mereka untuk memikirkan dengan matang pendapat yang akan mereka kemukakan, untuk kemudian dikirim ke alamat milis.

\section{METODE PENILITIAN}

Penelitian ini bertujuan untuk mengetahui kualitas diskusi online mahasiswa dengan menggunakan bahasa Inggris. Untuk mengetahui kualitas tersebut penelitian ini menggunakan metode analisis konten (Content Analysis).

Atas dasar penentuan latar belakang dan identifikasi masalah di atas, maka penulis dapat mengambil perumusan masalah sebagai berikut:

1. Bagaimana kualitas diskusi online yang terjadi dalam forum diskusi tersebut?

2. Pada level manakah diskusi mereka yang paling dominan?

\section{Prosedur Pengumpulan Data}

Proses pengumpulan data diambil dari transkrip diskusi mahasiswa di forum diskusi online di kelas Teaching Learning with ICT-1 yang dilakukan di Program Studi Pendidikan Bahasa Inggris, FKIP, Universitas Tanjungpura. Penulis mengambil istilah episode untuk mengklasifikasikan pesan-pesan yang memiliki topik yang sama. Sepanjang September 2009 - Februari 2010, terdapat dua belas episode. Namun untuk penulisan artikel ini penulis memutuskan untuk mengambil tiga episode diskusi, yaitu episode tiga, sepuluh, dan sebelas. Masing-masing peserta diskusi akan diberikan label S1, S2, S3, dan seterusnya sesuai urutan di daftar nama hadir mahasiswa.

\section{A. Prosedur Pengolahan Data}

Proses pengolahan data akan menggunakan metode analisis konten untuk mengetahui lebih dalam tentang ide-ide yang terdapat pada 
masing-masing pesan. Analisis konten adalah teknik analisis untuk menghasilkan deskripsi yang objektif dan sitematik mengenai konten yang terungkap dalam suatu komunikasi. Model analisis konten yang akan digunakan sebagai acuan dalam mengolah data adalah model yang diperkenalkan oleh Gunawardena et al. (1997) yang berpusat pada interaksi sosial dalam bentuk argumen sebagai sarana konstruksi pengetahuan.

Tabel 1. Model Analisis Konten (Gunawardena et al., 1997)

\begin{tabular}{|c|c|}
\hline Deskriptor & Indikator \\
\hline $\begin{array}{l}\text { Fase 1: } \\
\text { Berbagi/membandingkan } \\
\text { informasi yang diterima }\end{array}$ & $\begin{array}{l}\text { A. Sebuah pernyataan atau observasi terhadap } \\
\text { pendapat } \\
\text { B. Sebuah pernyataan persetujuan dari satu atau } \\
\text { lebih peserta } \\
\text { C. Penguatan dengan contoh-contoh yang diberikan } \\
\text { oleh satu atau lebih peserta } \\
\text { D. Bertanya dan menjawab pertanyaan untuk } \\
\text { mengklarifikasi detil pernyataan } \\
\text { E. Definisi, deskripsi, atau indetifikasi terhadap } \\
\text { sebuah masalah }\end{array}$ \\
\hline $\begin{array}{l}\text { Fase } 2 \text { : menemukan dan } \\
\text { mengeksplorasi } \\
\text { ketidaksesuaian atau } \\
\text { inkonsistensi ide, } \\
\text { konsep, atau pernyataan }\end{array}$ & $\begin{array}{l}\text { A. Mengidentifikasi dan menegaskan } \\
\text { pertidaksetujuan } \\
\text { B. Bertanya dan menjawab pertanyaan untuk } \\
\text { mengklarifikasi sumber dan cakupan } \\
\text { pertidaksetujuan } \\
\text { C. Menyatakan kembali posisi peserta, dan } \\
\text { kemungkinan mengembangkan pendapat atau } \\
\text { pertimbangan yang didukung oleh pengalaman } \\
\text { peserta, literature, data formal, atau sumber- } \\
\text { sumber lain yang merepresentasikan sudut } \\
\text { pandang }\end{array}$ \\
\hline $\begin{array}{l}\text { Fase 3: Negosiasi } \\
\text { pengertian/konstruksi } \\
\text { pengetahuan }\end{array}$ & $\begin{array}{l}\text { A. Negosiasi atau klarifikasi istilah-istilah yang ada } \\
\text { B. Negosiasi terhadap tipe-tipe argument } \\
\text { C. Identifikasi area persetujuan diantara konsep yang } \\
\text { bertentangan } \\
\text { D. Pengajuan dan negosiasi pernyataan baru yang } \\
\text { mencakup persetujuan bersama, konstruksi } \\
\text { bersama } \\
\text { E. Pengajuan penyatuan atau pengakomodasian } \\
\text { metafora atau analogi }\end{array}$ \\
\hline
\end{tabular}




\begin{tabular}{|l|l|}
\hline $\begin{array}{l}\text { Fase 4: menguji dan } \\
\text { memperbaiki konstruksi } \\
\text { yang diajukan }\end{array}$ & $\begin{array}{l}\text { A. Pengujian sintesis yang diajukan terhadap } \\
\text { "menerima fakta" seperti yang dimiliki oleh peserta } \\
\text { dan atau budaya mereka }\end{array}$ \\
& $\begin{array}{l}\text { B. Pengujian terhadap skema kognitif yang ada } \\
\text { C. Pengujian terhadap pengalaman pribadi } \\
\text { D. Pengujian terhadap data formal yang dikumpulkan } \\
\text { E. Pengujian terhadap testimoni yang kontradiktif } \\
\text { dalam literature yang tersedia }\end{array}$ \\
\hline $\begin{array}{l}\text { Fase 5: pernyataan } \\
\text { persetujuan terhadap } \\
\text { konstruksi pengetahuan }\end{array}$ & $\begin{array}{l}\text { A. Penarikan kesimpulan terhadap persetujuan- } \\
\text { persetujuan yang ada }\end{array}$ \\
Bang baru & $\begin{array}{l}\text { B. Penerapan pengetahuan yang baru } \\
\text { Cernyataan metakognitif oleh peserta yang } \\
\text { menggambarkan pemahaman mereka bahwa } \\
\text { pemahaman atau cara berpikir mereka (skema } \\
\text { kognitif) telah berubah sebagai hasil dari interaksi. }\end{array}$ \\
\hline
\end{tabular}

B. Prosedur Analisis-Sintesis

Proses analisis akan dilakukan berdasarkan hasil yang didapatkan dari pengolahan data. Sedangkan tahapan sintesis akan dilakukan untuk membahas hasil yang didapat dari tahapan analisis.

C. Prosedur Pengambilan Kesimpulan

Dengan melakukan tahapan analisis-sintesis, maka penulis mengambil kesimpulan untuk menjawab rumusan masalah seperti yang telah dikemukakan di atas.

D. Prosedur Perumusan Kesimpulan dan Saran

Kesimpulan dan rekomendasi dirumuskan setelah melalui semua tahapan dengan tetap berdasarkan pada topik penelitian.

\section{HASIL PENILITIAN DAN PEMBAHASAN}

A. Analisis

Metode analisis konten diterapkan dalam untuk menganalisa tiga episode yang diambil penulis sebagai sampel. Tiga episode tersebut adalah:

a) Episode tiga, dengan topik ICT and Things Related to It yang dimulai dari tanggal 13 Oktober 200 sampai 7 November 2009.

b) Episode sepuluh, dengan topik Do You Believe that Learning Really Takes Place or Happens by Exploring the Internet? , yang dimulai dari tanggal 8 Desember 2009 sampai 22 Januari 2010.

c) Episode sebelas, dengan topik American Slang yang dimulai dari tanggal 14 Januari 2010 sampai 1 Februari 2010. 
Tiga episode di atas dianalisis dengan menggunakan model analisis konten milik Gunawardena et al. (1997). Penulis mengklasifikasikan masing-masing pesan berdasarkan fase yang terdapat dalam model analisis konten tersebut.

Dalam menganalsis keseluruhan episode yang terjadi di dalam diskusi tersebut, penulis menemukan bahwa sebagian besar dari pesanpesan tersebut berada di Fase 1 (Berbagi dan Membandingkan Informasi) dengan total pesan sebanyak 117 pesan. Pesan-pesan tersebut bervariasi dari indikator pertama sampai kelima dengan jumlah pesan yang sama untuk indikator satu dan dua. Pada fase kedua, terdapat 40 pesan yang menunjukkan inkonsistensi dalam menyatakan pendapat. Proses ini diikuti oleh fase ketiga dengan jumlah pesan sebanyak 36 pesan. Berdasarkan temuan diatas, dapat kita lihat bahwa sebagian besar pesan terklasifikasi di fase pertama, kedua, dan ketiga. Alur diskusi dapat dideskripsikan sebagai berikut:

1. Fase 1: Berbagi/membandingkan informasi yang diterima

Sebagian besar pesan yang berada pada tahapan awal ini. Contohnya adalah sebagai berikut:

Episode $3 \# 1$ :

"There's something bothering me; in our previous meetings we already have known that people most of the time related the term ICT to the Internet and I wonder is ICT always over the Internet? I mean, we know that ICT stand for Information Communication Technology, and still there are so many issues that related to ICT like TV, hand phone, etc. How about that?" [F.I/D] (posted by S29 on Tue Oct 13, 2009)

(Ada sesuatu yang mengganggu saya; di pertemuan pertama, kita telah mengetahui bahwa banyak orang berpikir istilah TIK berkaitan dengan Internet dan saya penasaran apakah TIK itu sendiri selalu berkaitan dengan Internet? Maksud saya, seperti kita ketahui bersama bahwa TIK adalah kependekan dari Teknologi Informasi dan Komunikasi, dan masih banyak lagi isu tentang ICT seperti penggunaan $T V$, telepon genggam, dll. Bagaimana dengan hal tersebut?[Fase 1/D, dikirim oleh S29, Selasa, 13 Oktober, 2009] )

Episode 11 \#1:

"I have a question for you all, and maybe, it is an interesting question. The question is, "are we wrong if we learn and moreover 
mastering "American Slang"? Whereas in fact, we are going to become a teacher that should teach students the formal English. What is your opinion?[F.I/D] Thanks for answering my question..." (posted by S19 on Thu Jan 14, 2010)

(Saya punya pertanyaan untuk kalian semua, dan mungkin ini pertanyaan yang menarik. Pertanyaannya adalah, "apakah salah jika kita belajar dan menguasai "American Slang”? Padahal, kita akan menjadi guru yang harus mengajarkan bahasa Inggris formal kepada siswa-siswa kita. Bagaimana pendapatmu? [Fase 1/D] Terima kasih atas jawabannya... [Dikirim oleh S19, Kamis, 14 Januari, 2010]).

2. Fase 2: Menemukan dan mengeksplorasi ketidaksesuaian atau inkonsistensi ide, konsep, atau pernyataan.

Contoh pesan di bawah ini menunjukkan alur diskusi yang bergerak dari fase pertama ke fase kedua dan ketiga dimana peserta diskusi mencoba untuk membawa diskusi ke level yang lebih tinggi. Contohnya adalah sebagai berikut:

Episode 3 \#9:

"i disagree with you, S6.. [PhII/A] because not only thing that connected to Internet can be included as ICT... Television, although it is not connected to Internet, but when it can give us information, especially about education, also can be included as ICT.. so does mobile phone,, S6, it is all about INFORMATION, COMMUNICATION, AND TECHNOLOGY.. so $i$ think everything that related to those three things is ICT." [F.II/C] (posted by S2 on Thu Oct 15, 2009)

(saya tidak setuju dengan anda, S6, ... [Fase 2/A] karena tidak hanya yang berhubungan dengan Internet saja yang dapat dikategorikan dalam TIK... Televisi, walaupun tidak terhubung dengan Internet, tapi jika itu bisa memberikan kita informasi, khususnya informasi pendidikan, itu juga dapat dikategorikan sebagai TIK. demikian juga dengan telepon genggam,,, S6, semua ini tentang TEKNOLOGI INFORMASI DAN KOMUNIKASI.. jadi saya pikir semua yang berhubungan dengan tiga hal di atas adalah TIK. [Fase 2/C, dikirim oleh S2, Kamis, 15 Oktober 2009]

Pesan di atas adalah contoh alur diskusi yang bergerak dari satu fase ke fase lain. Dapat dilihat juga bahwa mahasiswa termotivasi untuk mendukung pendapat, pernyataan persetujuan, atau pertidaksetujuan 
dengan contoh-contoh yang menarik atau langsung saja beralih ke fase ketiga dengan menegosiasikan pengertian/ konstruksi pengetahuan.

3. Fase 3: Negosiasi pengertian/konstruksi pengetahuan

Pada level ini, pesan-pesan yang dikirim oleh mahasiswa menunjukkan pemahaman dan analisis yang lebih mendalam dalam diskusi dengan bermacam indikator dalam menyampaikan pendapat mereka. Contohnya adalah sebagai berikut:

Episode 11 \#13:

"We are not wrong if we learn American slang, it is just to enlarge our knowledge about the language. [PhI/A] But i don't think so for mastering the American slang. I think it is useful to understand American slang, but it is not good idea to teach it for your students, since we will become a teacher. [PhII/A] We know that slang changes from day to day and from one environment to another, there is always a new words in American slang. Slang's use and style is not something that you can learn from a textbook. I think the standard English (formal english) is better. Maybe we can introduce American slang to our students, but just for enlarge their knowledge." [F. III/B,D] (posted by S6 on Thu Jan 21, 2010)

(Tidak salah jika kita mempelajari American Slang, karena itu hanya untuk menambah wawasan kita tentang bahasa Inggris [Fase 1/A]. Tapi saya tidak sampai berpikiran untuk menguasainya. Saya pikir itu bagus jika kita mengerti American Slang, tapi bukan ide yang baik jika kita mengajarkannya kepada siswa, mengingat posisi kita sebagai guru [Fase 2/A]. Seperti kita ketahui bersama, bahwa bahasa tersebut selalu berubah dari waktu ke waktu, maka akan selalu ada kata-kata baru. Penggunaan kata-kata seperti itu tidak akan kita temukan dalam buku teks manapun. Saya pikir bahwa bahasa Inggris formal mungkin lebih baik. Mungkin kita dapat memperkenalkan American Slang kepada siswa, tapi hanya sekedar untuk menambah pengetahuan mereka. [Fase 3/B,D, dikirim oleh S6, Kamis, 21 Januari 2010]

4. Menguji dan memperbaiki konstruksi yang diajukan

Pesan-pesan yang terklasifikasi dalam fase ini menunjukkan proses konstruksi pengetahuan telah terjadi sebagai akumulasi dari diskusi yang telah terjadi sebelumnya dan sampai pada tahapan menguji dan memperbaiki konstruksi yang diajukan. Contohnya adalah sebagai berikut: 
Episode 10 \#30:

"S14, May I ask you one more question??

You wrote that we can browse it by ourselves, we can get many information about everything that we want to know. Your opinion is about searching the material by ourselves, right? What if we find it difficult for us to understand the material on the Internet? You know that we will not receive an immediate response to our questions and comments. This can be very frustrating, you know, especially if we are stuck in the material that we get confuse about .." [F.IV/B] (posted by S6 on Tue Jan 5, 2010)

(S14, Bolehkah saya mengajukan pertanyaan sekali lagi?

Anda menuliskan bahwa kita dapat mencarinya sendiri, kita dapat menemukan banyak informasi tentang apapun yang ingin kita ketahui. Pendapatmu berkisar tentang mencari materi sendiri, kan? Bagaimana jika kita tidak mengerti materi yang tersedia di Internet? Seperti yang kita ketahui bahwa kita tidak akan menerima respon atas pertanyaan atau komentar kita dengan segera. Ini bisa membuat kita frustasi, terlebih jika kita terjebak dengan materi yang membingungkan ..[Fase 4/B, dikirim oleh S6, Selasa, 5 Januari, 2010])

Pesan yang dikirim oleh S6 dimulai dengan menyatakan kembali pernyataan dari S14 yang tidak disetujuinya, kemudian dia melanjutkan dengan mengajukan sebuah pertanyaan untuk menguji skema kognitif S14.

5. Fase 5: Pernyataan persetujuan terhadap konstruksi pengetahuan yang baru Pesan yang menunjukkan proses diskusi yang berlangsung di fase terkahir ini adalah sebagai berikut:

Episode 3 \#6:

"Eem, I agree with u guys [PhI/B] even before I thought television can not be, for we can not share and argue about the resources or ideas by television. But after I think it back ICT is information and communications technology, ICT is not only related with Internet, there many technology things that can give as information. Although ICT identical with computer and Internet. Thanks for S29." [F.V/C] (posted by S5 on Wed Oct 14,)

(Eem, saya sependapat dengan kalian semua [Fase 1/B] walaupun sebelumnya saya pikir televisi tidak termasuk dalam TIK, karena kita 
tidak dapat bertukar pikiran tentang tayangan yang ada di televisi. Tapi setelah saya pikir kembali, TIK adalah teknologi informasi dan komunikasi, TIK tidak harus selalu berhubungan dengan Internet, banyak sekali selain Internet yang menyediakan infromasi. Walaupun sebenarnya TIK identik dengan komputer dan Internet. Terima kasih untuk S29. [Fase 5/C, dikirim oleh S5, Rabu, 14 Oktober 2009])

\section{B. Sintesis}

Dari hasil analisa yang telah dilakukan, penulis menemukan alur diskusi terjadi di semua fase. Sebagian besar pesan berada pada fase pertama, kedua, dan ketiga. Hal ini menunjukkan kualitas diskusi yang cukup baik karena peserta telah melalui proses bertukar pikiran, menemukan ketidakcocokan pendapat yang terjadi selama diskusi, serta mampu mengkonstruksi pengetahuan dalam bentuk kesimpulan dari proses diskusi yang telah dijalani.

Pada episode ketiga, diskusi dimulai dengan sebagian besar pesan berpusat di fase pertama seperti memberikan pendapat, contoh dalam kehidupan sehari-hari, serta mengidentifikasi masalah yang muncul. Setelah itu, alur diskusi bergerak ke fase yang lebih tinggi, yaitu fase kedua. Di fase ini, peserta diskusi mulai menyadari adanya perbedaan pandangan dan interpretasi yang terjadi diantara mereka. Hal tersbut diungkapkan dengan menyatakan ketidaksetujuan mereka beserta alasannya, dan diperkuat dengan contoh-contoh, pengalaman pribadi, serta data-data yang relevan. Permulaan fase ketiga ditandai dengan adanya dua ide yang saling bertentangan. Masing-masing pihak mencoba mempertahankan pendapatnya dengan memberikan penjelasan yang lebih mendalam. Beberapa dari mereka juga mencoba mendiskusian pernyataan-pernyataan baru yang membawa mereka pada tahapan mengkonstruksi pengetahuan. Fase selanjutnya, yaitu fase pengujian dan modifikasi terhadap sintesis yang diajukan, ditemukan pada beberapa pesan yang hampir semuanya terfokus pada proses menguji skema kognitif dari peserta diskusi yang lain. Walaupun jumlah pesan yang terdapat pada fase ini relatif sedikit, tapi hal ini telah menunjukkan bahwa proses konstruksi pengetahuan telah terjadi dalam diskusi di episode ini.

Serupa dengan apa yang telah terjadi di episode ketiga, sebagian besar pesan yang ada di episode keempat ini juga terpusat di fase pertama, kedua, ketiga, dan beberapa di fase keempat. Walaupun tidak ada pesan yang terklasifikasi di fase kelima, tapi episode ini memiliki jumlah pesan terbanyak diantara episode-episode lainnya. Pada awalnya, diskusi berjalan sedikit monoton karena sebagian besar peserta sependapat dengan topik diskusi. Memasuki pertengahan diskusi, beberapa peserta mulai 
menunjukkan ketidaksetujuannya dengan memberikan pernyataan baru yang bertolak belakang dengan topik yang diberikan. Mereka juga menambahkan beberapa contoh dan referensi yang sesuai untuk memperkuat pendapat mereka. Kehadiran dua pihak yang saling bertentangan dari segi ide dan pendapat ini melahirkan sebuah tahapan baru dimana pengujian terhadap sintesis yang diajukan dan skema kognitif dilakukan sebagai cara untuk membuat diskusi menjadi lebih aktif. Sayangnya, tidak ada kesimpulan yang dibuat sampai diskusi di episode ini berakhir.

Episode kesebelas memiliki jumlah pesan paling sedikit dibanding dengan yang lainnya, yaitu sebanyak dua puluh pesan. Sama halnya dengan dua episode yang telah dibahas sebelumnya, sebagian besar pesan terpusat pada fase pertama, kedua, dan ketiga. Diskusi yang terjadi di episode ini tidak ada satupun yang terklasifikasi baik pada fase keempat maupun kelima. Di awal diskusi, sebagian besar peserta memiliki pendapat yang sama. Pernyataan tidak setuju terhadap pendapat yang ada mulai muncul ditanda dengan adanya beberapa pesan yang mengajukan pendapat baru dan membawa diskusi ke tahap kosntruksi pengetahuan.

Pada umumnya, diskusi di forum ini berlangsung dengan baik. Pesanpesan tersebar merata dari fase pertama hingga fase kelima, walaupun dengan jumlah yang bervariasi untuk masing-masing fase. Pergerakan alur diskusi menunjukkan bahwa peserta diskusi mengkonstruksi pengetahuan mereka dengan pertama-tama memberikan pendapat mereka tentang topik diskusi dan kadang-kadang mereka juga mencoba menghubungkannya dengan beberapa contoh dan referensi yang sesuai. Pendapat mereka bisa saja diterima atau ditolak oleh peserta diskusi yang lain. Jika pendapat mereka diterima, maka mereka telah menyumbangkan pengetahuan baru bagi yang lainnya. Jika tidak, maka diskusi akan terus berlanjut ke tahapan berikutnya. Pada akhirnya, rangkaian proses di atas akan membawa peserta diskusi pada tujuan utama adanya diskusi itu sendiri, yaitu proses mengkonstruksi pengetahuan dengan menggunakan forum diskusi online sebagai media.

\section{KESIMPULAN DAN SARAN}

Forum diskusi yang telah digunakan dalam mata kuliah Teaching Learning with ICT-1 adalah hal baru dan pengalaman baru bagi mahasiswa. Ia merupakan venue untuk melatih berkomunikasi dan berdiskusi akademis. Dan hal ini memang digunakan oleh mahasiswa untuk berdiskusi sesama mereka. Dari data penelitian ini seperti yang digambarkan di atas dapat disimpulkan bahwa: 
1. Walau mahasiswa sebenarnya bisa berkomunikasi tentang apa saja, kapan saja, dan dimana saja, sepenjang mereka memiliki akses terhadap Internet, mereka masih sangat berfokus pada guru (teacher centred). Mereka tidak memulai diskusi kecuali apabila dosen mereka memulai dengan pertanyaan-pertanyaan awal. Dan partisipasi mereka sebenarnya terbatas pada jawaban atas pertanyaan dosen mereka. Dengan demikian tujuan bahwa teknologi adalah untuk mendorong mahasiswa supaya memiliki kesempatan yang sama dalam proses pembelajaran belum begitu tercapai.

2. Kualitas diskusi mereka belum begitu memuaskan. Apa yang mereka ungkapkan dalam diskusi adalah perspektif pribadi yang belum didasarkan pada referensi yang sebenarnya telah dibagikan kepada mereka sebelum perkuliahaan dimulai. Hal ini menjadi tantangan tersendiri bagi dosen untuk melatih berdiskusi dalam konteks ilmiah.

Walaupun dengan dua fenomena diatas, yang menarik dari penelitian ini adalah bahwa ternyata partisipasi diskusi meningkat walau sangat teacher centred. Harapannya diskusi menjadi hal yang lumrah. Berdasarkan teori social constructivism yang mendasari penelitian ini diskusi menjadi wadah mahasiswa tidak hanya berlatih mengungkapkan pendapat tapi yang lebih penting adalah berbagi ilmu dengan berbagai perspektif dan pengalaman masing-masing individu.

Penelitian serupa masih perlu dilakukan khususnya untuk memperbaiki model komunikasi yang dalam riset ini masih didominasi oleh model teacher centred.

\section{DAFTAR PUSTAKA}

Banrit, P. S. (2007). Using Technology In and Beyond the Language Classroom. Oxford: Macmillan Publishers.

Carliner, S. 2004 An overview of online learning, $2^{\text {nd }}$ edition, HRD Press Inc., Massachussets.

Duff, P. A. (2008). Case Study Research in Applied Linguistics. New York: Taylor \& Francis Group.

Garrison, D. R., Anderson, T., \& Archer, W. (2001). Critical thinking, cognitive presence and computer conferencing in distance education. The American Journal of Distance Education, 15(1), 7-23.

Gunawardena, C. L., Lowe, C.A., \& Anderson, T. (1997). Analysis Of Global Online Debate and The Development of An Interaction Analysis Model For Examining Social Construction Of Knowledge in Computer 
Conferencing. Journal Educational Computing Research, 17 (4), $397-$ 431.

Hew, KF., \& Cheung, WS. Attracting student participation in asynchronous online discussions: A case study of peer facilitation. Computers \& Education 51, 1111-1124.

Jyothi, S., McAvini, C., Keating, J. (2012) A visualisation tool to aid exploration of students' interactions in asynchronous online communication. Computers \& Education, 58 (1) 30-42.

Samuel, C. (2001). Computer-Mediated Communication:A Motivator in the Foreign Language Classroom. The Korea TESOL Journal , 119-132.

Scheuermann, F., Larsson, K., \& Toto, R. (2003). Learning in virtual environments - facilitating interaction and moderation. In CSCL 2003: Proceedings of International Conference of Computer-Supported Collaborative Learning. Bergen: CSCL.

Stacey, E. and Philippa G. 2009 Effective blended learning practices: evidence based perspectives in ICT-facilitated education, Information Science Reference, New York.

Suryadi, A. (2007). Pemanfaatan ICT dalam Pembelajaran. Jurnal Pendidikan Terbuka dan Jarak Jauh, 83-98.

Wahono, Romi Satria. 2005. Pengantar e-Learning dan Pengembangannya. Ilmukomputer.com

Zuchdi, Darmiyati. 1993. Panduan Penelitian Analisis Konten. Yogyakarta: Lembaga Penelitian IKIP Yogyakarta. 